\title{
An International Perspective on the Teacher Qualities Issue: the Case of Croatia and Turkey
}

\author{
Višnja Rajić', Tuğba Hoşgörür² and Maja Drvodelić \\ ${ }^{\prime}$ Faculty of Teacher Education University of Zageb \\ ${ }^{2}$ Muğla Sıtkı Koçman Üniversitesi
}

\section{Abstract}

It is a well-known fact that the quality of the education system depends greatly on the quality of the teacher (Buchanan, 2012). Therefore, it is clear that it is important for prospective teachers to develop competences and qualities necessary for their future profession in the course of their education. This paper aims to find out how prospective teachers from Croatia and Turkey evaluate the importance and required level of personal and professional qualities. This research was conducted on a sample of 1004 prospective primary school teachers attending the first and final year of study (500 from Croatia and 504 from Turkey). The results show that Croatian prospective teachers evaluate personal and professional qualities as significantly more important, and that they believe to have higher possession of these qualities than their Turkish colleagues. Overall, prospective teachers in their final year of study evaluate that they have significantly more developed professional skills than their first year colleagues.

Key words: personal teacher qualities; professional teacher qualities; prospective teachers; teacher education.

\section{Introduction}

Teacher quality is a wide term and many authors use different approaches to define it. Starting from the terminology point, teacher quality is used when trying to define highly qualified teachers, effective teachers and good teachers (Liston et. al, 2008). The term highly qualified teacher is most commonly used by education policy makers such as ministries or boards of education when trying to describe teachers' qualifications. One of the examples is No Child Left Behind federal law (2001) where 
highly qualified teachers are defined as those teachers who meet three criteria: a state teaching certification and/or a bachelor's degree licensed by the state, and competences in the academic subject area they teach.

An effective teacher is a term that refers to teacher ability to foster student achievements (Liston et al., 2008) which shifts focus on the achievement outcomes rather than qualifications. Teacher effectiveness is expressed most commonly in terms of student academic achievement, an element more easily (and less expensively) measured than some other essential outcomes of good education (Leu, 2005). To be efficient, teachers must develop a sense of professional identity that successfully incorporates their personal subjectivities into the professional/cultural expectations of what it means to be a "teacher" (Alsup, 2005). There is a collective view of what it means to be a professional teacher, as well as a collective responsibility for maintaining this professionalism. On the other hand, professionalism also has an individual side. This is the professionalism of individual teachers, resulting from their personal values and their conception of the teacher they want to be (Education Council, 2013). The term effective teacher is commonly used by the researchers and can often be found in literature referring to educational, school, teacher and student quality. Although currently, there is no single, widely accepted definition of teacher quality, Looney (2011,pp. 441-442) makes a synthesis of the studies carried out so far and names the following qualities of effective teachers describing them as professionals who: are intellectually able (verbal skills are particularly important), have good knowledge of the subject-area(s) and a broad repertoire of teaching methods and strategies to meet, develop positive relationships with their students and recognise the crucial role of motivation and emotions in learning, have strong classroom management skills, including clarity in the presentation of ideas, well-structured lessons and appropriate pacing, are skilled assessors and work collaboratively with their peers to develop a positive school climate, to improve overall school performance, and to engage in mutual support and professional learning. A good teacher is the most widely used, but also very flexible and least precise term. It refers to teachers' work methods, skills, knowledge, attitudes, opinions, etc. To be a good teacher, ideally, would mean that there is a complete "alignment" of the teacher's behaviour, competences, beliefs, identity and mission, together forming one coherent whole matching the environment; a situation that can take a lifetime to attain, if it is ever attained at all (Korthagen, 2004). Good teachers are described as teachers who consistently obtain high learning growth from their students. Poor teachers are, therefore, the opposite, i.e. teachers who consistently produce low learning growth of their students (Hanushek, 2002). A term good teacher is most often used in an educational practice and it is used by researchers, parents, students, teachers and general public. A definition that combines all three perspectives is given by Cohen et al. (1998): “... to perform effectively, a teacher should possess an impressive body of knowledge and a considerable amount of qualities". Regardless of the terminology preference and whether we use the terms highly qualified, efficient or good teacher, teachers are the most important element 
of an education system (Kavcar, 2002), for they are the most important school-level factor affecting student achievement (Looney, 2011). To be more precise, Buchanan (2012) indicates in his study that teachers should be accepted as the most important stakeholders in improving the quality of education and in order to do so it is crucial to educate and train them for excellence. The professionalism of teachers is a key factor in the realization of good education (Onderwijsraad, 2012).

According to the Education Council (2013), since the teaching profession is multidisciplinary and complex, teacher education should be multidisciplinary and research-based. It should ensure that teachers have extensive subject knowledge, a good knowledge of pedagogy, the skills and competences required to guide and support their learners, and an understanding of the social and cultural dimensions of education. The teaching profession should be well qualified, i.e. teachers should be graduates from a higher education institution or equivalent (Tuning, 2009). The National Council for the Accreditation of Teacher Education in the United States stresses the importance of teacher preparation programmes and they indicate that teacher preparation helps pre-service teachers develop the knowledge and skills they need in the classroom. They mention that well prepared teachers produce more successful students and that they are more likely to remain in teaching (National Council for the Accreditation of Teacher Education, [NCATE], n.d., 3). One of the biggest and most influential reforms in education systems in Europe was the implementation of the Bologna process in higher education (http://www.ehea.info/). Even though it aimed to harmonize educational systems across Europe, national policies still shape higher education in different ways, resulting in diverse possibilities in teacher education (The teaching profession in Europe: Profile, Trends and Concerns, 2002).

\section{Initial Teacher Education (ITE) in Croatia}

Teachers who work in primary schools in Croatia are either class teachers who teach all subjects from grade 1 to 4 (lower primary school, ISCED 1), or subject teachers who teach only one subject from grade 5 to 8 (upper primary school, ISCED 2).

Before the implementation of the Bologna process, lower primary school teachers (class teachers) attended colleges known as "teacher training colleges" which were mostly part of university systems as higher professional schools. Those institutions offered higher level professional programmes for pre-primary and lower primary school teachers. Education for lower primary school teachers lasted four years ( 8 semesters) ending with a professional BA degree. Subject teachers for upper primary school and secondary school were educated at universities where academic contents and educational sciences and teaching methodologies were organised simultaneously. Such programmes lasted for four years ending with a university BA degree (Domović \& Vizek Vidović, 2011). Croatia signed the Bologna Declaration at the Ministerial conference in Prague in 2001, and since the implementation of the Bologna process in the academic year 2005/2006 the greatest change in ITE occurred for class teachers who advanced from 4-year-long higher professional schools to the integrated single 
cycle $(5+0)$ undergraduate and graduate university level which lasts for 5 years $(10$ semesters) after which students acquire their master's degrees in education (300 ECTS). The introduction of these changes has opened the possibilities for further development of postgraduate and doctoral studies in this area (Domović \& Vizek Vidović, 2010). Subject teacher programmes which lasted four years were transformed into two cycles (3+2): BA level (180 ECTS credits) and MA level (120 ECTS credits). At the BA level, students mostly take two disciplines (academic subjects), while educational studies, teaching methodologies and teaching practice are studied at master's level (Domović $\&$ Vizek Vidović, p. 265, 2011). When students acquire 300 ECTS points they receive the professional title Master of Education in specific disciplines.

\section{Initial Teacher Education (ITE) in Turkey}

Turkey signed the Bologna Declaration in 2001, the same year as Croatia. But the reconstruction of education faculties started earlier, in 1998. In 1997, the length of primary education in Turkey was changed from 5 to 8 years. So, one of the reasons why the reconstruction in teacher education was necessary resided in the need for teachers who would teach the last 3 years of primary education (YOK, 1998). Primary school teachers took part in the first five years. But for the last three years, they needed teachers who specialized to teach in primary schools.

After the reconstruction process, the only primary school teaching departments became 5 -year-long programmes. For primary school teaching, only the content of the programmes changed and the length of the programmes stayed the same (4 years). Besides, before the reconstruction process, primary school teaching was just a programme in the education faculties. But then, primary school teaching became a department and these departments had different programmes like primary school mathematics teaching. In addition, in 2006, teacher training programmes were updated, as a part of the changes after Turkey's accession to the European Higher Education Area. According to these changes, $50 \%$ of the courses involve subjectmatter knowledge, $30 \%$ teaching profession and skills and $20 \%$ of them involve general knowledge courses. After completing all the courses in 4 years of training, primary school teachers obtain a total of 240 ECTS credits. Faculties only have the right to determine about $25 \%$ of their courses. Other than this, all teacher training programmes have the same system (YOK, 2008). And for the 2012/2013 teaching semester, a big and sudden change occurred in Turkish education system; 8-year-long primary education was divided into two separate parts $(4+4)$. The first 4 years formed primary schools (ISCED 1) where primary school teachers teach now. This sudden change caused an oversupply of primary school teachers in Turkey.

\section{Teacher Competences}

It is expected, no matter the country they come from, that by the end of their formal education pre-service teachers need to acquire the necessary competences for efficient teaching and facilitating their students' learning. Competences represent a dynamic 
combination of cognitive and metacognitive skills, knowledge and understanding, interpersonal, intellectual and practical skills, and ethical values (TUNING, 2009). Teacher competences include knowledge, skills and attitudes required to perform the teaching profession effectively and efficiently. Common European Principles for Teacher Competences and Qualifications (European Commission, 2005) state three key teacher competences: Work with others, Work with knowledge, technology and information, Work with and in society. In Turkey, the Ministry of National Education made a detailed study about the competences of teachers and identified six main competences: personal and professional values-professional development, knowing the student, learning and teaching process, monitoring and evaluation of learning and development, school-family and society relationships, knowledge of curriculum and content. Under these competences, there are 31 subcompetences and 233 performance indicators (MoNE, 2006, p. 3). Teacher education in Croatia has undergone significant changes in the last decade, and still, when developing new programmes, defining of the national standards in the area of professional teacher competences was left out (Domović, 2009, p.16). While waiting for the national standards of teacher competences to be developed and announced, each Teacher Education faculty in Croatia developed a list of teacher competences based on their study programme outcomes. An example of such a list of competences can be found in the Proposal for the new Teacher education programme at the Faculty of Teacher Education of the University of Zagreb (2012) where the following generic competences are listed: understanding and critical thinking about the educational process and the interdependence of its elements; understanding, critical thinking and the ability to develop teacher identity; acting according to ethical standards of the profession and in the best interests of the pupil; understanding of all of the actors of the educational process, and the ability of quality communication, cooperative and team work; understanding and the ability to use appropriate scientific and research work in education; understanding and the ability to participate in the development of scholastic and pedagogical pluralism; accountability for professional development and lifelong learning including the ability to analyse and evaluate personal work, educational process and learning; communication skills and knowledge of the Croatian language; the ability to apply ICT and media in the educational context. As a result of constant work on the creation of national standards for teacher competences, a theoretical background has been made and published in the book Praćenje i vrednovanje profesionalnog razvoja učitelja- kompetencijski pristup (Vizek Vidović et al., 2014), and it will serve as a reference point for the development of future national teacher competences in Croatia.

\section{Teacher Qualities}

The qualities of a good teacher are not easy to identify or inculcate. Still, it is important to develop the understanding of what they are so that we can set a standard that teachers can strive to achieve. There are different views on what teacher qualities are. Teacher qualities are intrinsic resources that teachers have even before they finish 
pre-service initial education and are employed. Teacher qualities include beliefs, attitudes, values, personal traits, knowledge, skills, and expertise and credentials (Kennedy, 2008). Ofman (2000) maintains that the distinction between core qualities and competences lies primarily in the fact that qualities come from the inside while competences are acquired from the outside. Tickle (1999) argues that empathy, compassion, understanding, tolerance, love and flexibility are the essential qualities of teachers. When describing personal qualities, some researchers (Ofman, 2000, Tickle, 1999; Beijaard et al., 2005) use the term core qualities. Teacher qualities are divided by Drvodelić and Rajić (2011), and Hosgorur (2012) into personal and professional qualities. Personal qualities correspond to Ofman's core qualities (e.g. patient, creative, outgoing) and professional qualities that are more competence based qualities (e.g. objective, just). Korthagen (2013, p. 132) states that an integration of core qualities with competences is important because core qualities give a personal colour to the execution of competences. This study gives a comparative perspective in order to give an answer to the question whether teacher qualities are perceived in the same way in different cultures. Increasingly more attention is being paid to the beliefs people have about themselves, referring to how one defines oneself, in other words, to how a person sees his or her (professional) identity (Korthagen, 2004). In one of the studies, Liu and Meng (2009) compared qualities of a good teacher in China with those of a good teacher in the USA. According to the findings, teacher qualities were classified into four categories as: teacher ethics, professional skills, professional development and teaching effects, and it is concluded that the qualities of a good teacher in China are consistent with those identified in the USA.

This research is founded on two previous research cycles which were conducted by Drvodelić and Rajić (2011) in Croatia and Hosgorur (2012) in Turkey with an aim to identify the opinions of pre-service primary school teachers about the desirable and acquired qualities of a good teacher as a set of personal and professional traits/ characteristics that make a good teacher. Given results were used as a starting point of this study.

\section{Methodology}

\section{Research Aim}

The aim of the study was to determine the differences between the opinions of Croatian and Turkish pre-service primary school teachers about the desirable and possessed qualities of a good teacher, regarding their educational level.

\section{Sample}

The sample of this study included 504 pre-service primary school teachers from Muğla Sıtkı Koçman University, Adnan Menderes University and Anadolu University from Turkey, and 500 pre-service primary school teachers from the University of Zagreb, University of Rijeka, University of Split and Josip Juraj Strossmayer University 
of Osijek from Croatia. The sample included first and final year students, hence first and fourth year students in Turkey and first and fifth year students in Croatia. That summed to a total of 1004 participants who filled the questionnaires correctly.

\begin{tabular}{lcccc}
$\begin{array}{l}\text { Table } 1 \\
\text { Details of the sample group } \\
\text { COUNTRY }\end{array}$ & $\begin{array}{c}\text { N } \\
\text { (Universities) }\end{array}$ & Year of study & $\begin{array}{c}\mathrm{N} \\
\text { (Students) }\end{array}$ & $\begin{array}{c}\mathrm{N} \\
\text { (Students Total) }\end{array}$ \\
\hline Turkey & 3 & first & 268 & 504 \\
& & final & 236 & \\
Croatia & 4 & first & 255 & 500 \\
& & final & 245 & \\
Total & & & & 1004
\end{tabular}

\section{Procedures and Instruments}

The data of this study was collected by means of the "Evaluation of Teacher Qualities" questionnaire which was developed by the researchers of this study. The questionnaire was constructed by using the findings of the previous studies by Drvodelić and Rajić (2011) and Hosgorur (2012). In those previous studies pre-service teachers in Croatia and in Turkey were asked to think of five qualities that make a good teacher, write them down and rank them by importance. During further data analysis and reduction processes teacher qualities that were listed five times or more were organized into two categories: personal qualities and professional qualities. The lists of teacher qualities from both research studies were combined into a list of 28 teacher qualities that were used in this study. Only the qualities that were listed 10 times or more by Croatian and/or Turkish students were selected.

Table 2

Personal and professional teacher qualities determined by pre-service teachers in Croatia and/or Turkey

\begin{tabular}{lcclcc}
\hline Personal qualities & TUR & CRO & Professional qualities & TUR & CRO \\
\hline Patient & $\mathrm{X}$ & $\mathrm{X}$ & Just & $\mathrm{X}$ & $\mathrm{X}$ \\
Tolerant & $\mathrm{X}$ & $\mathrm{X}$ & Professional & $\mathrm{X}$ & $\mathrm{X}$ \\
Understanding & $\mathrm{X}$ & $\mathrm{X}$ & Expert on subject matter & $\mathrm{X}$ & \\
Good communicator & $\mathrm{X}$ & $\mathrm{X}$ & Having wide general knowledge & $\mathrm{X}$ & \\
Positive & $\mathrm{X}$ & $\mathrm{X}$ & Committed to work & $\mathrm{X}$ & \\
Warm & $\mathrm{X}$ & $\mathrm{X}$ & Disciplined & $\mathrm{X}$ & \\
Empathetic & $\mathrm{X}$ & $\mathrm{X}$ & Open to new ideas & & $\mathrm{X}$ \\
Democratic & $\mathrm{X}$ & & Reliable & $\mathrm{X}$ \\
Respectful & $\mathrm{X}$ & & Objective & $\mathrm{X}$ \\
Humanitarian & $\mathrm{X}$ & & Hardworking & & $\mathrm{X}$ \\
Having a good diction & $\mathrm{X}$ & & Authoritative & & $\mathrm{X}$ \\
Creative & & $\mathrm{X}$ & Motivated & & $\mathrm{X}$ \\
Resourceful & & $\mathrm{X}$ & Organized & & $\mathrm{X}$ \\
Outgoing & & $\mathrm{X}$ & & & \\
Honest & & $\mathrm{X}$ & & & \\
\hline
\end{tabular}


Personal and professional teacher qualities were integrated into a five point scale "Evaluation of Teacher Qualities" questionnaire that consisted of two parts. In the first part, pre-service teachers were asked to assess how important it is for a good teacher to possess each of the 28 listed qualities and in the second part they were asked to assess to what degree they possess each of those 28 listed qualities. The questionnaire was prepared in English by the authors of this study. Afterwards, it was translated into the Croatian and Turkish language. Alongside each quality a precise explanation of its meaning was presented in order to assure the validity of the questionnaire in both languages. Some qualities that had similar meanings in previous studies were brought together under the same nomination (e.g. smiley/positive=positive; affectionate/ warm=warm, etc.). Finally, the translation was proofread by language experts and after the necessary changes were made, the questionnaire was implemented. The data was collected in the spring semester of 2011/2012 academic year both at Croatian and Turkish universities.

\section{Results and Discussion}

For the purpose of further analysis the existing variables were computed into 4 composites according to their semantic content (composite 1: desirable personal qualities, composite 2: desired professional qualities, composite 3: personal qualities possessed, composite 4: professional qualities possessed).

Personal qualities were constructed from 15 variables that describe qualities such as resourcefulness and humour and personal characteristics such as patience, creativity, altruism and so on. The same variables were used to asses both desired and possessed personal qualities. The construct of professional qualities, for both desired and possessed qualities, consists of 13 variables describing professional qualities such as openness to new ideas and work commitment, and professional characteristics such as reliability, objectivity and so on. Since the reliability analysis showed high reliability for each composite ( $\alpha 1=0.820 ; \alpha 2=0.818 ; \alpha 3=0.804 ; \alpha 4=0.849)$, those composites were used for all the following analyses.

Table 3

Mean values, standard deviation, minimum and maximum values, reliability and the number of variables of each composite

\begin{tabular}{lcccccc}
\hline & N & M & SD & Min & Max & a \\
\hline composite 1:desirable personal teacher qualities & 15 & 4.61 & .299 & 3 & 5 & 0.820 \\
composite 2: desirable professional teacher qualities & 13 & 4.53 & .353 & 3 & 5 & 0.818 \\
composite 3: possessed personal teacher qualities & 15 & 4.30 & .352 & 3 & 5 & 0.804 \\
composite 4: possessed professional teacher qualities & 13 & 4.15 & .454 & 2 & 5 & 0.849 \\
\hline
\end{tabular}

Exploration of the overall data showed that the students evaluate both the desirability and the possession of the teacher qualities quite high (Table 3). Although the results are high, there is a noticeable difference between the assessment of important and possessed teacher qualities. When asked to assess how important it is for a teacher to 
have a certain characteristic, students focused on teachers in general, or on an ideal teacher as they see him/her. When asked to assess the level of their possession of a certain quality, students reflected on their teaching practice and evaluated themselves, which lead to somewhat lower results. Such results show that students have a vision of a good teacher and at the same time recognize that they still have some space for personal and professional growth.

When the mentioned qualities (Table 2) which are different for the two countries are analysed, it is seen that the Croatian students described a good teacher as creative, resourceful, outgoing and honest in which their answers differed from those given by the Turkish students. Cubukcu (2006) found out in her study determining the critical thinking dispositions of Turkish pre- service teachers that these teacher candidates got the highest score in the open-mindedness dimension. It is explained that a high score in open-mindedness indicates that the individual is tolerant to different approaches and does not only consider their own thoughts but also the thoughts of others while making decisions. Therefore, the expectations of pre-service teachers, according to which a good teacher needs to be respectful, democratic and humanitarian, is consistent with their critical thinking abilities which were determined in Cubukcu's (2006) study. When the professional teacher qualities that were mentioned by the Croatian and Turkish pre-service teachers are analysed, the results showed that both groups agreed on a good teacher being just and professional. When the different qualities are examined, it is seen that Croatian pre-service teachers mostly focused on "how" a good teacher "performs" the teaching (being open to new ideas, reliable, objective, hardworking, etc.). However, Turkish pre-service teachers mostly stress the "knowledge based" qualities (being an expert on the subject matter, having wide general knowledge, etc.). The results also showed that the Croatian students evaluate the importance of personal and professional teacher qualities as well as their possession higher than the Turkish students (Table 4). These results are interesting and can be partially explained with the differences between the pre-service teacher education systems of Croatia and Turkey.

One of the possible explanations of higher results obtained by the Croatian preservice teachers could be the length of the pre-service teacher education. Some benefits of long term teacher education are pointed out in the TELT study which showed that university-based preservice programmes had more influence on teacher training than the school-based programmes did (Kennedy, 1999). It could be assumed that because the Croatian students have a one-year longer teacher education programme than the Turkish students do, they view themselves more positively. Another possible difference that could have made an impact on the results is the different approach taken in Croatia and Turkey to the selection system of teachers for public schools. In Turkey, after they obtain their degree from education faculties, pre-service teachers need to take an exam called the public personnel selection examination. There is a quota system for teacher selection formed by using the ranking in this exam. But the 
number of teachers they hire is rather limited compared to the number of the annual pre-service teacher graduates. Therefore, most of the graduates will be unemployed, as there are not enough teaching positions. Kildan et al. (2013) aimed to evaluate the views of teacher trainees on the teacher training system in Turkey and concluded that the teachers who were in their first year in the profession indicated this examination as one of the most important problems of the teacher training process in Turkey. Consequently, the problems that await the pre-service teachers when they graduate might affect their motivation towards the profession and also their understanding of what a good teacher should be like. They might have fewer expectations from the teaching profession compared to the pre-service teachers in Croatia. In Croatia, although there is an excess of primary teachers, all of the teachers that finalize their studies successfully have equal opportunities to be employed.

When exploring the differences according to the year of the study, the results show that there are no differences in student evaluations of the desired professional qualities according to the study level (Table 4). The rating of the desired professional qualities is quite high throughout the course of the study. These results show that the pre-service teachers at the starting point of their study have a developed understanding of the importance of the professional qualities of a teacher as part of their teacher identity (Korthagen, 2004) that tends to stay an important part of their understanding of the teaching profession.

Table 4

Mean value of the importance and possession of personal and professional qualities according to the country and the year of study of the participants

\begin{tabular}{|c|c|c|c|c|c|c|c|c|}
\hline & \multicolumn{4}{|c|}{ Croatia } & \multicolumn{4}{|c|}{ Turkey } \\
\hline & \multicolumn{2}{|c|}{$\begin{array}{l}1^{\text {st }} \text { year } \\
N=255\end{array}$} & \multicolumn{2}{|c|}{$\begin{array}{l}5^{\text {th }} \text { year } \\
N=245\end{array}$} & \multicolumn{2}{|c|}{$\begin{array}{l}1^{\text {st }} \text { year } \\
N=268\end{array}$} & \multicolumn{2}{|c|}{$\begin{array}{l}5^{\text {th }} \text { year } \\
N=236\end{array}$} \\
\hline & $\begin{array}{l}\text { Personal } \\
\text { qualities }\end{array}$ & $\begin{array}{l}\text { Professional } \\
\text { qualities }\end{array}$ & $\begin{array}{l}\text { Personal } \\
\text { qualities }\end{array}$ & $\begin{array}{l}\text { Professional } \\
\text { qualities }\end{array}$ & $\begin{array}{l}\text { Personal } \\
\text { qualities }\end{array}$ & $\begin{array}{c}\text { Professional } \\
\text { qualities }\end{array}$ & $\begin{array}{l}\text { Personal } \\
\text { qualities }\end{array}$ & $\begin{array}{c}\text { Professional } \\
\text { qualities }\end{array}$ \\
\hline importance & $M=4.69$ & $M=4.65$ & $M=4.65$ & $M=4.68$ & $M=4.61$ & $M=4.32$ & $M=4.57$ & $M=4.32$ \\
\hline possession & $M=4.52$ & $M=4.15$ & $M=4.39$ & $M=4.30$ & $M=4.53$ & $M=3.83$ & $M=4.42$ & $M=3.95$ \\
\hline
\end{tabular}

On the other hand, on an overall sample there are differences between students of the first and the final year in the construct of the possessed professional qualities. Students who were in their final year of study evaluated the possession of professional teacher qualities higher than their colleagues in the first year of study (Table 5). Goodson and Cole (1994) claim that the prospective teachers' sense of developing a (new) professional identity is contextually dependent on their developing notions of the professional community. Therefore, the time spent in the institutions for teacher education has influenced the development of their professional identity. During the period of pre-service teacher education, both Croatian and Turkish students have academic courses that empower them and help them to develop in the areas of the teaching profession and teaching skills. A combination of pedagogical and 
psychological knowledge, teaching methods courses, subject matter knowledge, and courses specialized to raise awareness about the teaching profession (such as teaching practice courses) lead to the professional development of pre-service teachers. These results were expected and can confirm the positive effect of teacher education on preservice teachers' opinions on the acquisition level of the professional teacher qualities. No differences were found in the areas of both desired and possessed personal qualities according to the year of study. This could be explained with Ofmans's (2001) theory that core qualities (or personal qualities as the authors call them in this article) are not acquired from the outside, therefore they cannot be influenced from the outside during the course of pre-service teacher education. Those are the qualities that each person has in them even before they enrol university. Although these qualities cannot be acquired on purpose, they can be influenced by raising awareness and building capacities for their usage through activities that take place in the study courses.

Table 5

Main effects and interaction of the country and the year of study for the value of the importance and possession of personal and professional competence

\begin{tabular}{llrl}
\hline Source & Dependent Variable & \multicolumn{1}{c}{$\mathrm{F}$} & Sig. \\
\hline Year of study & Possesion of professional qualities & 23.712 & .000 \\
& Posession of personal qualities & .566 & .452 \\
& Desirable professional qualities & .065 & .799 \\
& Desirable personal qualities & 2.677 & .102 \\
\hline Country & Possesion of professional qualities & 141.828 & .000 \\
& Posession of personal qualities & 29.867 & .000 \\
& Desirable professional qualities & 215.445 & .000 \\
& Desirable personal qualities & 26.383 & .000 \\
\hline \multirow{2}{*}{ Year* Country } & Possesion of professional qualities & .286 & .593 \\
& Posession of personal qualities & .191 & .662 \\
& Desirable professional qualities & .004 & .949 \\
& Desirable personal qualities & .677 & .411 \\
\hline
\end{tabular}

\section{Conclusion}

According to the findings of this study, it was concluded that, in all dimensions of this study, Croatian pre-service teachers evaluate both the importance and the possession levels of teacher qualities higher than Turkish pre-service teachers.

When comparing the systems of both countries, the first difference seen is in the length of the primary school teaching programmes. The results indicate that the length of initial teacher education can have a constructive impact on students' perceptions of their developed professional teacher qualities. Alsup (2005) has indicated that although pre-service teachers' professional identity formation is quite personal, teacher preparation programmes can make a difference.

The difference between the evaluations of personal qualities with regard to the year of the study is not significant on an overall sample. The research findings confirm Ofmans' (2001) claims that personal qualities are not acquired from the outside. And 
since they are not acquired from the outside, they cannot be influenced from the outside by the education level, and do not change significantly according to the year of study. Dall Alba (2009) states that during their studies in teacher education prospective teachers continue to be the persons they are. At the same time, these prospective teachers undergo change in their capacity to teach and in their understanding of what teaching involves.

The main difference was found in the evaluation of professional qualities on an overall sample. Prospective teachers in their final year of study evaluate the possession of their professional qualities significantly more positive than those students in their first year of study. Teacher professionalism is complex, it is embedded in the context of shared norms, values, and views in an occupational group, but it is also personal and individual. The results of this research show that focusing on "individual professionalism" and individual values during their years of study can make a significant change in the professional identities of the prospective teachers. Pelton (2013) focuses on the impact area of teacher training programmes and mentions that besides efficacy, teacher training programmes can even decrease anxiety about teaching. Chong et al. (2011) state that most discourse on teacher identity has been focused on its formation during beginning teaching years and throughout the career. Much less has been researched on the subject of teacher identity during the early years of teacher preparation, and even less on the extent of the changes in teacher identity that occur between entry to exit points of pre-service preparation. Prospective teachers seem to have a clear idea and are able to identify what makes a good and quality teacher. The difference is that students in the last year of their study perceive themselves as being more professional.

However, we should be careful when interpreting these results. Since there was no additional evaluation of teacher qualities (personality scales, or peer evaluation), these results show only the personal opinions of the pre-service teachers.

Alsup (2005) states that feeling successful as a teacher is attached to a sense of professional identity that integrates the intellectual, the emotional, and the physical aspects of the teacher's life as well as taking on the subjectivities of "teacher." Meaning that the teachers should be able to combine the "core" identity or personal beliefs and sense of self with the professional identity.

The importance of a good/effective/successful teacher is globally recognised, and yet most people think that teachers are leaving teacher preparation programmes without the necessary knowledge and skills they need to be effective practitioners (Hodgman, 2012, p. 223). Maandag et al. (2007) also put an emphasis on this and say that teacher education programmes are criticized for not providing the professional training required by today's societies. So, it is of great importance that during their time at the university, opportunities for prospective teachers to explore and identify their core and professional qualities are insured in order to enable them to develop professional identity, personal pedagogies and a clear mission. We conclude agreeing 
with Korthagen (2004) who proposes a more holistic approach towards teacher development, in which competence is not equated with competences.

\section{References}

Alsup, J. (2005). Teacher identity discourses: Negotiating personal and professional spaces. UK: Lawrence, Erlbaum Associates, Inc.

Beijaard, D. et al. (Eds.) (2005). Teacher Professional Development in Changing Conditions. Netherlands: Springer. http://dx.doi.org/10.1007/1-4020-3699-X

Buchanan, J. (2012). Improving the quality of teaching and learning: A teacher-as-learnercentred approach. International Journal of Learning, 18 (10), 345-356.

Cohen, L., Manion, L., \& Morrison, K. (1998). A guide to teaching practice. (4 $4^{\text {th }}$ ed.). London: Routledge.

Cubukcu, Z. (2006). Critical thinking dispositions of the Turkish teacher candidates. The Turkish Online Journal of Educational Technology, 5 (4), 22-36.

Dall'Alba, G. (2009). Learning Professional Ways of Being: Ambiguities of becoming: Educational Philosophy and Theory, 41 (1), 34-45. http://dx.doi.org/10.1111/j.14695812.2008.00475.x

Darling-Hammond, L. (2006). Powerful Teacher Education: Lessons from Exemplary. San Francisco: Jossey-Bass.

Domilescu, G. (2011). Teacher training: developments and prospects in teacher training across the European Union. Journal of Educational Sciences, 13 (1), 55-61.

Domović, V. (2009). Kurikulum-osnovni pojmovi. In V. Vizek Vidović (Ed.), Planiranje kurikuluma usmjerenog na kompetencije u obrazovanju učitelja i nastavnika (pp. 19-32). Zagreb: Filozofski i Učiteljski fakultet Sveučilišta u Zagrebu.

Domović, V., \& Vizek Vidović, V. (2010). Development of quality culture in initial teacher education in Croatia. In B. Hudson, P. Zgaga, \& B. Astrand (Eds.), Advancing Quality Cultures for Teachers Education in Europe: Tensions and Opportunities (pp. 105-120). Umea: Umea School of Education, Umeå University.

Domović, V., \& Vizek Vidović, V. (2011). Teacher education in Croatia: Recent developments in teacher education (2005-2010). In M. Valenčič Zuljan, J. Vogrinc (Eds.), European dimensions of teacher education - similarities and differences (pp. 253-270). Ljubljana: Faculty of Education, University of Ljubljana.

Drvodelić, M., \& Rajić, V. (2011). Prospective primary school teacher views on personal and professional qualities. Practice and Theory in Systems of Education, 6 (1), 47-56.

Education Council (2013). Being a teacher: More focus on personal professionalism. Den Haag: Onderwijsraad.

European Commission (2001). European report on the quality of school education. Italy: European communities.

Faculty of Teacher Education, University of Zagreb (2012). Proposal for the program for initial teacher education. Zagreb: University of Zagreb.

Goodson, I. F., \& Cole, A. L. (1994). Exploring the teacher's professional knowledge: Constructing identity and community. Teacher Education Quarterly, 21(1), 85-105. 
Hanushek, E. (2002). Teacher quality. In L. Izumi, \& W. Evers (Eds.), Teacher Quality (pp.112). Palo Alto: Hoover Institution.

Hodgman, M. R. (2012). Boundaries and applications: The teacher quality debate in America. Journal of College Teaching \& Learning, 9 (3), 223-227.

Hosgorur, T. (2012). A Discussion of what makes a good teacher: Opinions of pre-service primary school teachers. Procedia-Social and Behavioral Sciences, 55, 451-460. http:// dx.doi.org/10.1016/j.sbspro.2012.09.524

Kavcar, C. (2002). Cumuriyet Döneminde dal öğretmeni yetiştirme. [Training of elementary and secondary school teachers in Republic Period.] Ankara University, Journal of Faculty of Educational Sciences, 35 (1-2), 1-14. http://dx.doi.org/10.1501/Egifak_0000000058

Kennedy, M. (2008). Sorting out Teacher Quality. Phi Delta Kappan, Vol 90. No.1. pp. 59-63. http://dx.doi.org/10.1177/003172170809000115

Kennedy, M. M. (1999). The role of preservice teacher education. In L. Darling-Hammond \& G. Sykes (Eds.), Teaching as the Learning profession: Handbook of Teaching and Policy (pp. 54-86). San Francisco: Jossey Bass.

Kildan, A. O., Ibret, B. U., Pektas, M., Aydinozu, D., Incikabi, L., \& Recepoglu, E. (2013). Evaluating views of teacher trainees on teacher training process in Turkey. Australian Journal of Teacher Education, 38 (2), 51-68. http://dx.doi.org/10.14221/ajte.2013v38n2.10

Korthagen, F.A.J. (2004). In search of the essence of a good teacher: towards a more holistic approach in teacher education. Teaching and Teacher Education, 20, 77-97. http://dx.doi. org/10.1016/j.tate.2003.10.002

Korthagen,F. A. J., Kim, M. Y., \& Green,W. L. (Eds.) (2013). Teaching and Learning from Within: A Core Reflection Approach to Quality and inspiration in education. New York: Routhledge.

Leu, E., \& Price-Rom, A. (2006). Quality of Education and Teacher Learning: A Review of the Literature. Washington, DC: USAID Educational Quality Improvement Project.

Liston, D., Borko, H., \& Whitcomb, J. (2008). The teacher educator's role in enhancing teacher quality. Journal of Teacher Education, 59(2), 111-116. http://dx.doi. org/10.1177/0022487108315581

Liu, S., \& Meng, L. (2009). Perceptions of teachers, students and parents of the characteristics of good teachers: a cross-cultural comparison of China and the United States. Educational Assessment, Evaluation and Accountability, 21 (4), 313-328. http://dx.doi.org/10.1007/ s11092-009-9077-z

Looney, J. (2011), Developing High-Quality Teachers: teacher evaluation for improvement. European Journal of Education, 46, (4), 440-455. http://dx.doi.org/10.1111/j.14653435.2011.01492.x

Maandag, D.W., Deinum J.F., Hofman, W. H. A., \& Buitink, J. (2007). Teacher education in schools: an international comparison, European Journal of Teacher Education, 30 (2), 151173. http://dx.doi.org/10.1080/02619760701275552

Ministry of National Education (2006). Generic teacher competencies /online/. Retrieved on $12^{\text {th }}$ March 2012 from http://otmg.meb.gov.tr/belgeler/otmg/Generic_Teacher Competencies.pdf

National Council for Accreditation of Teacher Education (n.d.). What makes a teacher effective: a summary of key research findings on teacher preparation? /online/. Retrieved on $14^{\text {th }}$ December 2012 from http://www.ncate.org/LinkClick.aspx?fileticket=JFRrmWqa1 $\mathrm{jU} \% 3 \mathrm{~d} \&$ tabid $=361$ 
Ofman, D. (2000). Core qualities: A gateway to human resources. Schiedam: Scriptum.

Pelton, J.A. (2013). Assessing graduate teacher training programmes: Can a teaching seminar reduce anxiety and increase confidence?. Teaching Sociology /online/. Retrieved on $13^{\text {th }}$ November 2013 from http://tso.sagepub.com/content/early/2013/05/23/00920 55X13500029.

Schnurr, N. V., Racic, S., \& Gelo, T. (2011). University students' attitudes: Croatia versus Turkey, Journal of International Education Research, 7 (2), 23-32.

Smith, J. C. \& Laslett, R. (1996). Effective classroom management: a teacher's guide. (2 $\left.{ }^{\text {nd }} \mathrm{ed}.\right)$. London: Routledge.

The teaching profession in Europe: Profile, Trends and Concerns. (2002). /online/. Retrieved on $12^{\text {th }}$ June 2012 from http://www.eurydice.org/ressources/eurydice/pdf/0_ integral/037EN.pdf

Tickle, L. (1999). Teacher self-appraisal and appraisal of self. In R. P. Lipka, \& T. M. Brinthaupt (Eds.), The role of self in teacher development (pp. 121-141). Albany, NY: State University of New York Press.

TUNING (2009). Reference Points for the design and Delivery of Degree Programmes in Education-education brochure. /online/. Retrieved on $15^{\text {th }}$ May 2012 from

http://www.unideusto.org/tuningeu/images/stories/Publications/Education_brochure. pdf

Vizek Vidović, V., Domović, V., \& Marušić, I. (2014). Praćenje i vrednovanje profesionalnog razvoja učitelja- kompetencijski pristup. Zagreb: NCVVO.

YÖK (Yüksek Öğretim Kurulu)[Higher Education Council]. (1998). Reorganization of teacher training programmes of education faculties. Ankara: Higher Education Council publications.

YÖK. (2008). Teacher training and education faculties. Ankara: Higher Education Council publications.

\section{Višnja Rajić}

Faculty of Teacher Education University of Zagreb, Savska cesta 77, 10000 Zagreb, Croatia visnja.rajic@ufzg.hr

\section{Tugba Hosgorur}

Muğla Sıtkı Koçman Üniversitesi

Kötekli Mh., 48000 Kötekli/Muğla, Turkey

t.hosgorur@mu.edu.tr

\section{Maja Drvodelić}

Faculty of Teacher Education University of Zagreb,

Savska cesta 77, 10000 Zagreb, Croatia

maja.drvodelic@ufzg.hr 


\section{Problem kvalitete nastavnika s međunarodnoga gledišta: slučaj Hrvatske i Turske}

\section{Sažetak}

Poznato je da kvaliteta obrazovnoga sustava uvelike ovisi o kvaliteti nastavnika (Buchanan, 2012). Prema tome, jasno je koliko je važno da budući učitelji tijekom obrazovanja razviju kompetencije i kvalitete potrebne za svoje buduće zanimanje. Cilj je ovoga rada istražiti kako budući učitelji iz Hrvatske i Turske ocjenjuju važnost osobnih i profesionalnih kvaliteta i u kojoj ih mjeri posjeduju. Istraživanje je provedeno na uzorku od 1004 buduća osnovnoškolska učitelja koji su pohađali prvu i završnu godinu studija (500 iz Hrvatske i 504 iz Turske). Rezultati pokazuju da budući učitelji iz Hrvatske ocjenjuju svoje osobne i profesionalne kvalitete znatno važnijima i da smatraju kako ih posjeduju na znatno višoj razini od svojih turskih kolega. Ispitanici cjelokupnog uzorka budućih učitelja koji pohađaju posljednju godinu studija ocjenjuju da imaju znatno razvijenije profesionalne vještine od svojih kolega koji pohađaju prvu godinu studija.

Ključne riječi: budući učitelji; obrazovanje učitelja; osobne kvalitete učitelja; profesionalne kvalitete učitelja.

\section{Uvod}

Kvaliteta učitelja širok je pojam koji mnogi autori različito definiraju. S gledišta terminologije, termin kvaliteta učitelja upotrebljava se kako bi se definirali visokoobrazovani učitelji, učinkoviti učitelji i dobri učitelji (Liston i dr., 2008). Termin visokokvalificiran učitelj najčešće upotrebljavaju tvorci obrazovnih politika (primjerice ministarstva i odbori za obrazovanje) za opis kvaliteta učitelja. Jedan primjer je federalni zakon (2001) „Ni jedno dijete se ne ostavlja“, prema kojemu visokokvalificirani učitelji udovoljavaju trima kriterijima: imaju državnu učiteljsku diplomu i/ili bakalar i kompetencije iz akademskih predmeta iz kojih su predmetni nastavnici.

Termin učinkovit učitelj odnosi se na sposobnost učitelja da potakne i razvije učeničko postignuće (Liston i dr., 2008), a danas se usredotočuje na ishode postignuća radije nego na kvalifikacije. Učinkovitost učitelja najčešće se izražava u obliku učeničkoga akademskoga postignuća. Taj je element jednostavnije (i jeftinije) mjeriti 
od nekih drugih osnovnih rezultata dobroga obrazovanja (Leu, 2005). Da bi bili učinkoviti, učitelji moraju razviti osjećaj profesionalnoga identiteta koji uspješno uključuje njihovu osobnu subjektivnost u profesionalna/kulturološka očekivanja o tome što to znači biti „učitelj“ (Alsup, 2005). Postoji kolektivno mišljenje o tome što to znači biti profesionalni učitelj i što je to kolektivna odgovornost za održavanje profesionalizma. S druge strane, profesionalizam ima i individualnu stranu. Radi se o profesionalizmu individualnih učitelja koji proizlazi iz njihovih osobnih vrijednosti i predodžbi o tome kakvi učitelji pojednici žele biti (Education Council, 2013). Autori se često koriste terminom učinkovit učitelj i obično ga se nalazi u literaturi koja se bavi obrazovnim, školskim, učiteljskim i učeničkim kvalitetama. Iako trenutno nema jedinstvene i široko prihvaćene definicije kvalitete učitelja, Looney (2011, str. 441442) sažima dosad provedena istraživanja i imenuje sljedeće kvalitete učinkovitih učitelja, opisujući ih kao profesionalce koji su intelektualno sposobni (govorne vještine osobito su važne), posjeduju dobro znanje područja koje podučavaju i širok repertoar metoda podučavanja i strategija za susret s učenicima i razvoj pozitivnoga odnosa s njima. Također vješto prepoznaju ključnu ulogu motivacije i emocija u učenju, posjeduju dobre vještine upravljanja razredom, jasno prezentiraju svoje zamisli, dobro strukturiraju nastavu koju održavaju tempom primjerenim učenicima, vješti su u ocjenjivanju te surađuju s kolegama u cilju razvoja pozitivnog školskog okruženja sa svrhom unapređenja opće školske izvedbe i izgrađivanja mreže međusobne podrške i profesionalnog učenja. Termin dobar učitelj često se koristi, ali je on vrlo fleksibilan i neprecizan. Odnosi se na metode rada učitelja, njihove vještine, znanja, stavove, mišljenja i sl. Biti dobar učitelj značilo bi postići potpuno „poravnanje“ učiteljeva ponašanja, vještina, vjerovanja, identiteta i misije. Sve to trebalo bi činiti jednu koherentnu cjelinu koja je prilagođena okolini. Da bi se to postiglo, potreban je jedan životni vijek, ako se to uopće i uspije (Korthagen, 2004). Dobri su učitelji oni koji kod svojih učenika konstantno postižu visok razvoj učenja. Loši učitelji, dakle, predstavljaju upravo suprotnost dobrim učiteljima. To su učitelji koji kod svojih učenika konstantno postižu nizak razvoj učenja (Hanushek, 2002). Terminom dobar učitelj u obrazovnoj se praksi često koristi znanstvenici, roditelji, učenici, učitelji i šira javnost. Cohen i dr. (1998) daju definiciju koja obuhvaća sva tri gledišta te kaže da „za učinkovitu izvedbu učitelj mora posjedovati impresivnu količinu znanja i kvaliteta". Neovisno o tome služimo li se terminima visokokvalificiran, učinkovit ili dobar učitelj, učitelji su najvažniji element obrazovnoga sustava (Kavcar, 2002) jer predstavljaju najvažniji školski čimbenik koji utječe na učeničko postignuće (Looney, 2011). Preciznije, Buchanan (2012) u svojem radu navodi da učitelji moraju biti prihvaćeni kao najvažniji sudionici u unapređenju kvalitete obrazovanja, a da bi to učinili, ključno je obrazovati ih za postizanje izvrsnosti. Profesionalizam učitelja ključan je čimbenik u realizaciji dobroga obrazovanja (Onderwijsraad, 2012).

S obzirom na to da je učiteljsko zanimanje višedisciplinarno i kompleksno, i obrazovanje učitelja trebalo bi biti višedisciplinarno i utemeljeno na istraživačkom 
radu (Education Council, 2013). Treba učiteljima osigurati mogućnosti za stjecanje temeljitog znanja predmeta koje će podučavati, dobrog znanja pedagogije, vještina i kompetencija potrebnih za vođenje i pružanje podrške učenicima, kao i razumijevanje društvenih i kulturoloških dimenzija edukacije. Učitelji trebaju biti dobro kvalificirani, primjerice trebali bi imati visokoškolsku diplomu (Tuning, 2009). Nacionalno vijeće za priznavanje učiteljskih diploma (The National Council for the Accreditation of Teacher Education) u Sjedinjenim Američkim Državama naglašava važnost programa obrazovanja učitelja te smatra da takvo obrazovanje budućim učiteljima pomaže razviti znanje i vještine koje su im potrebne u razredu. Također spominju da dobro pripremljeni učitelji produciraju uspješnije učenike te je tim vjerojatnije i da će nastaviti raditi kao učitelji (National Council for the Accreditation of Teacher Education, [NCATE], n.d., 3). Implementacija Bolonjskoga procesa u visoko obrazovanje predstavlja jednu od najvećih i najutjecajnijih reformi edukacijskih sustava u Europi (http://www.ehea.info/). Usprkos tome što je cilj Bolonjskoga procesa bio harmonizirati obrazovne sustave u Europi, nacionalne politike još uvijek formiraju visoko obrazovanje na različite načine, što rezultira različitim mogućnostima u obrazovanju nastavnika (The teaching profession in Europe: Profile, Trends and Concerns, 2002).

\section{Početno obrazovanje učitelja (POU) u Hrvatskoj}

Učitelji koji rade u osnovnim školama u Hrvatskoj dijele se na razredne učitelje koji podučavaju sve predmete od 1. do 4. razreda (niža osnovna škola, ISCED 1), i predmetne nastavnike koji podučavaju samo jedan predmet od 5. do 8. razreda (viša osnovna škola, ISCED 2).

Prije implementacije Bolonjskoga procesa učitelji u nižim razredima osnovnih škola (razredni učitelji) pohađali su institucije višeg obrazovanja, poznatije pod nazivom „pedagoške akademije“, koje su većinom u sveučilišne sustave bile uključene kao više profesionalne škole. Te su institucije osiguravale visokokvalitetne profesionalne programe namijenjene budućim predškolskim i osnovnoškolskim učiteljima. Obrazovanje učitelja nižih razreda osnovnih škola trajalo je četiri godine (8 semestara) te je završavalo diplomom bakalara. Predmetni su se nastavnici, koji su poslije radili u višim razredima osnovnih škola i u srednjim školama, bili obrazovali na fakultetima na kojima su u isto vrijeme pohađali kolegije koji su se bavili akademskim sadržajima i kolegije koji su se bavili obrazovnim znanostima i metodologijama podučavanja. Takvi su programi trajali četiri godine te su završavali sveučilišnom diplomom (Domović, Vizek Vidović, 2011). Hrvatska se pridružila Bolonjskom procesu 2011. godine na Ministarskoj konferenciji u Pragu. Od trenutka implementacije Bolonjskoga procesa u školskoj godini 2005./2006. najveća promjena koja se odnosila na razredne učitelje sastojala se u tome da se od obrazovanja koje je prethodno trajalo 4 godine u visokim školama prešlo na sustav integriranoga petogodišnjega obrazovanja $(5+0)$ dodiplomskog i diplomskog sveučilišnog studija (10 semestara). Nakon takvoga 
obrazovnog razdoblja studenti sad stječu magisterij iz obrazovanja (300 ECTS bodova). Uvođenje tih promjena otvorilo je mogućnosti za daljnji razvoj poslijediplomskih i doktorskih studija u navedenom području (Domović, Vizek Vidović, 2010). Programi koje su pohađali studenti budući predmetni nastavnici sad se izvode u dva ciklusa $(3+2)$ pa studenti tako stječu akademski stupanj bakalara (180 ECTS bodova) i magistra (120 ECTS bodova). Na prvom stupnju (bakalarat) studenti najčešće upisuju dvopredmetne studije, a obrazovne se znanosti, metodologije podučavanja i nastavna praksa podučavaju na drugom stupnju (magisterij) (Domović, Vizek Vidović, p.265, 2011). Nakon što studenti prikupe 300 ECTS bodova, stječu profesionalnu diplomu magistra obrazovnih znanosti u određenoj disciplini.

\section{Početno obrazovanje učitelja (POU) u Turskoj}

Turska je potpisala Bolonjsku deklaraciju 2001. godine, iste godine kao i Hrvatska, no rekonstrukcija učiteljskih fakulteta započela je prije, 1998. godine. Trajanje osnovnoškolskog obrazovanja u Turskoj je 1997. godine promijenjeno s 5 na 8 godina. Tako je rekonstrukcija obrazovanja učitelja bila potrebna, između ostalog, zbog potebe za učiteljima koji bi podučavali učenike u posljednje tri godine osnovnoškolskoga obrazovanja (YOK, 1998). Osnovnoškolski su učitelji podučavali prvih pet godina osnovne škole, no za posljednje su tri godine trebali učitelje koji bi specijalizirali podučavanje u osnovnim školama.

Nakon procesa rekonstrukcije samo su odsjeci za podučavanje osnovnoškolskih učitelja postali petogodišnji programi. Za osnovnoškolske učitelje promijenjen je samo sadržaj programa, a duljina je programa ostala ista (4 godine). Osim toga, prije procesa rekonstrukcije, obrazovanje osnovnoškolskih učitelja predstavljalo je samo program na obrazovnim fakultetima. No tad je osnovnoškolsko obrazovanje postalo odsjek, a odsjeci su imali različite programe, npr. podučavanje osnovnoškolske matematike. Uz to su 2006. godine programi obrazovanja učitelja unaprijeđeni. To je bio dio promjena koje je Turska provela nakon ulaska u Europski prostor visokog obrazovanja. Kao dio tih promjena, 50\% kolegija sad obuhvaća predmetno znanje, 30\% znanje metodologije podučavanja, a $20 \%$ su opći kolegiji. Nakon što polože sve kolegije u vremenu od 4 godine, osnovnoškolski učitelji stječu ukupno 240 ECTS bodova. Fakulteti imaju pravo definirati samo 25\% svojih kolegija, a ostatak je programa isti za sve fakultete (YOK, 2008). U semestru 2012. - 2013., velika i nagla promjena dogodila se u turskom obrazovnom sustavu. Osmogodišnje je obrazovanje podijeljeno $\mathrm{u}$ dva dijela (4+4). Prve 4 godine formirale su osnovne škole (ISCED 1) u kojima sad podučavaju osnovnoškolski učitelji. Ta nagla promjena uzrokovala je prevelik broj diplomiranih osnovnoškolskih učitelja u Turskoj.

\section{Kompetencije učitelja}

Bez obzira na to iz koje zemlje dolaze, od učitelja se očekuje da do kraja svojega formalnoga obrazovanja steknu kompetencija neophodne za učinkovito 
podučavanje i vođenje njihovih učenika u procesu učenja. Stečene kompetencije predstavljaju dinamičku kombinaciju kognitivnih i metakognitivnih vještina, znanja i razumijevanja, međuljudskih, intelektualnih i praktičnih vještina te etičkih vrijednosti (TUNING, 2009). Kompetencije učitelja obuhvaćaju znanja, vještine i stavove potrebne za učinkovito snalaženje u njihovom budućem zanimanju. Zajednički europski principi učiteljske/nastavničke kompetencije i kvalifikacije (European Commission, 2005) određuju tri ključne kompetencije učitelja: Raditi s drugima; Raditi sa znanjem, tehnologijom i informacijama; Raditi s društvom i u društvu. U Turskoj je Ministarstvo nacionalnoga obrazovanja izradilo detaljnu studiju učiteljskih kompetencija i utvrdilo šest glavnih kompetencija, a to su: razvoj osobnih i profesionalnih vrijednosti, profesionalni razvoj, poznavanje učenika, proces učenja i podučavanja, praćenje i ocjenjivanje učenja i razvoja, odnosi između škole-obitelji i društva, znanje kurikuluma i predmetnoga sadržaja. $U$ ove je kompetencije uključena 31 podkompetencija i 233 indikatora izvedbe (MoNE, 2006, 3). Obrazovanje učitelja u Hrvatskoj u posljednjem je desetljeću prošlo značajne promjene. Ipak, pri razvoju novih programa izostala je definicija nacionalnih standarda u području profesionalnih kompetencija učitelja (Domović, 2009, str.16). Dok su čekali da se razviju i objave nacionalni standardi za učiteljske komeptencije, svaki je učiteljski fakultet u Hrvatskoj razvio svoj popis učiteljskih kompetencija koji je bio utemeljen na ishodima njihovih studijskih programa. Jedan je primjer vidljiv u Prijedlogu za novo obrazovanje učitelja na Učiteljskom fakultetu Sveučilišta u Zagrebu (2012) u kojemu su navedene sljedeće temeljne kompetencije: razumijevanje i kritičko promišljanje odgojnoobrazovnih procesa i međuovisnosti pojedinih dijelova odgojno-obrazovnog sustava; razumijevanje, kritičko promišljanje i sposobnost razvoja identiteta učiteljske profesije; djelovanje u skladu s etičkim standardima profesije i najboljim interesom učenika; razumijevanje i uvažavanje svih dionika odgojno-obrazovnog procesa te sposobnost kvalitetne komunikacije, suradničkoga i timskog rada; razumijevanje, poznavanje i upotreba odgovarajućih postupaka znanstveno-istraživačkog rada u području odgoja i obrazovanja; razumijevanje i osposobljenost za sudjelovanje u razvoju školskog i pedagoškog pluralizma; preuzimanje odgovornosti za vlastiti profesionalni razvoj i cjeloživotno učenje, uključujući sposobnost analize i vrednovanja vlastitoga rada, odgojno-obrazovnih procesa i učenja; jezično-komunikacijska znanja i vještine na hrvatskom jeziku; sposobnost usmene i pisane komunikacije na stranom jeziku za potrebe osobnog i profesionalnog razvoja učitelja s naglaskom na receptivne vještine koje omogućuju upućeno praćenje stručne literature relevantne za učiteljsku struku; sposobnost samostalne primjene informacijsko-komunikacijske tehnologije i medija u odgojno-obrazovnom kontekstu.

Rezultat stalnog nastojanja izrade nacionalnih standarda učiteljskih kompetencija je i izrada teoretske podloge koja je predstavljena u knjizi Praćenje i vrednovanje profesionalnog razvoja učitelja - kompetencijski pristup (Vizek Vidović i dr., 2014) koja će poslužiti kao referenca za razvoj budućih nacionalnih kompetencija učitelja u Hrvatskoj. 


\section{Kvalitete učitelja}

Kvalitete dobroga učitelja nije lako utvrditi niti usaditi. Ipak je važno razviti razumijevanje o tome što one jesu kako bi se postavio standard kojemu učitelji mogu stremiti. Kvalitete učitelja intrinzična su sredsta koja oni posjeduju još prije nego završe studij i zaposle se. Kvalitete učitelja uključuju vjerovanja, stavove, vrijednosti, osobne karakteristike, znanja, vještine, stručnost i kvalifikacije (Kennedy, 2008). Ofman (2000) smatra da razlika između temeljnih kvaliteta i kompetencija leži primarno u činjenici da kvalitete dolaze iznutra, a kompetencije se stječu izvana. Tickle (1999) tvrdi da su temeljne učiteljske kvalitete empatija, suosjećanje, razumijevanje, tolerancija, ljubav i fleksibilnost. Neki se autori za opis osobnih kvaliteta koriste terminom temeljne kvalitete (Ofman 2000., Tickle, 1999; ur. Beijaard, 2005). Drvodelić i Rajić (2011) i Hosgur (2012) dijele kvalitete učitelja na osobne i profesionalne. Osobne kvalitete odgovaraju Ofmanovim temeljnim kvalitetama (npr. strpljiv, kreativan, otvoren) i profesionalnim kvalitetama koje se više temelje na kompetencijama (npr. objektivan, pravedan). Korthagen (2013, str. 132) kaže da je važno integrirati temeljne kvalitete s kompetencijama jer temeljne kvalitete daju osobnu boju izvršenju kompetencija. Navedeno istraživanje daje usporedno gledište sa svrhom pružanja odgovora na pitanje percipiraju li se kvalitete učitelja na isti način u različitim kulturama. Sve se više pažnje posvećuje vjerovanju koje ljudi imaju o sebi, a koje se odnosi na to kako se dobro osoba poznaje, odnosno kako osoba vidi svoj (profesionalni) identitet (Korthagen, 2004). U jednom su istraživanju Liu i Meng (2009) usporedili kvalitete dobroga učitelja u Kini s kvalitetama dobroga učitelja u SAD-u. Rezultati pokazuju da se kvalitete učitelja klasificiraju u četiri kategorije: učiteljeva etika, profesionalne vještine, profesionalni razvoj i učinci podučavanja te se zaključuje da su vještine dobroga učitelja u Kini u skladu s onima utvrđenim u SAD-u.

To se istraživanje temelji na dva prethodna istraživačka ciklusa koja su u Hrvatskoj provele Drvodelić i Rajić (2011), a u Turskoj Hosgorur (2012) s ciljem utvrđivanja mišljenja budućih osnovnoškolskih učitelja o poželjnim i stečenim kvalitetama dobroga učitelja kao skupa osobnih i profesionalnih karakteristika koje čine dobroga učitelja. Rezultati toga istraživanja upotrijebljeni su kao početna točka ovoga rada.

\section{Metodologija}

\section{Cilj istraživanja}

Cilj istraživanja bio je utvrditi razlike između mišljenja hrvatskih i turskih budućih osnovnoškolskih učitelja o kvalitetama dobroga učitelja koje su poželjne i koje oni posjeduju s obzirom na njihov stupanj obrazovanja.

\section{Uzorak}

U istraživanju su sudjelovala 504 turska buduća osnovnoškolska učitelja sa Sveučilišta Muğla Sitkı Koçman, Adnan Menderes i Anadolu i 500 hrvatskih budućih osnovnoškolskih učitelja sa Sveučilišta u Zagrebu, Sveučilišta u Splitu i Sveučilišta 
Josip Juraj Strossmayer u Osijeku. Uzorak se sastojao od studenata početne i završne godine, odnosno prve i četvrte u Turskoj i prve i pete u Hrvatskoj. Ukupno su 1004 ispitanika dobro ispunila upitnik.

Tablica 1.

\section{Procedura i instrumenti}

Podatci su prikupljeni uz pomoć upitnika za „Ocjenu kvaliteta učitelja“ koji su razvile autorice ovoga rada. Upitnik je izrađen na temelju prethodnih istraživanja koja su provele Drvodelić i Rajić (2011) i Hosgorur (2012). U tim prethodnim istraživanjima budući učitelji u Hrvatskoj i Turskoj upitani su da promisle o tome kojih pet kvaliteta čine dobrog učitelja. Trebali su te kvalitete napisati i rangirati ih prema njihovoj važnosti. Daljnjom analizom podataka i procesom redukcije kvalitete učitelja koje su navedene pet ili više puta organizirane su u dvije kategorije: osobne i profesionalne kvalitete. Popisi kvaliteta učitelja koje je pronašlo oboje istraživača uključen je na popis 28 kvaliteta učitelja koje su upotrijebljene u ovome istraživanju. Odabrane su samo one kvalitete koje su hrvatski i/ili turski studenti naveli 10 ili više puta.

Tablica 2.

Osobne i profesionalne kvalitete učitelja integrirane su u skalu od pet stupnjeva i navedene u upitniku „Ocjena kvaliteta učitelja “ koji se sastojao od dva dijela. U prvome dijelu budući su učitelji zamoljeni da ocijene koliko je za dobroga učitelja važno da posjeduje svaku od navedenih 28 kvaliteta, dok su u drugom dijelu trebali procijeniti do koje mjere oni sami posjeduju svaku od navedenih 28 kvaliteta. Upitnik su autorice pripremile na engleskom jeziku te je on naknadno preveden na hrvatski i turski. Da bi se uvjerili da je upitnik valjan na oba jezika, uz svaku je kvalitetu ubilježeno točno objašnjenje njezina značenja. Neke kvalitete koje su imale slična značenja u prethodnim istraživanjima navedena su pod istim nazivnikom (npr. vedar /nasmijan/pozitivan=pozitivan; susretljivost/otvorenost/toplina=toplina). Prijevod su potom pregledali stručnjaci jezikoslovci te je on implementiran nakon što su načinjene potrebne izmjene. Podatci su na hrvatskim i turskim sveučilišitma prikupljeni u ljetnom semestru ak. god. 2011./2012.

\section{Rezultati i raprava}

Postojeće su varijable na temelju njihova semantičkog sadržaja razdvojene u 4 kategorije (kategorija 1: poželjne osobne kvalitete, kategorija 2: željene profesionalne kvalitete, kategorija 3: osobne kvalitete koje ispitanik posjeduje, kategorija 4: profesionalne kvalitete koje ispitanik posjeduje).

Osobne su se kvalitete sastojale od 15 varijabli koje opisuju kvalitete kao što su snalažljivost I smisao za humor te osobne kvalitete kao što su strpljenje, kreativnost, altruizam itd. Iste su kvalitete upotrijebljene za ispitivanje željenih kvaliteta i osobnih kvaliteta koje ispitanik posjeduje. Kategorija profesionalnih kvaliteta (željenih i onih 
koje ispitanik posjeduje) sastoji se od 13 varijabli upotrijebljenih za opis profesionalnih kvaliteta kao što su otvorenost za nove ideje i predanost poslu te profesionalnih kvaliteta kao što su pouzdanost, objektivnost itd. Analiza pouzdanosti pokazala je visok stupanj pouzdanosti za svaku kategoriju $(\alpha 1=0.820 ; \alpha 2=0.818 ; \alpha 3=0.804 ; \alpha 4$ $=0.849$ ) te su one upotrijebljene u daljnjoj analizi.

\section{Tablica 3.}

Studenti ocjenjuju poželjnost i posjedovanje kvaliteta učitelja vrlo visokim ocjenama (Tablica 3). Ipak, vidljiva je razlika između ocjene važnih i posjedovanih kvaliteta učitelja. Kad su zatraženi da ocijene koliko je važno da učitelj ima određene karakteristike, studenti su se usredotočili na učitelje općenito, ili na idealnoga/idealnu učitelja/učiteljicu kako ga/je oni vide. Kad su upitani da ocijene razinu osobnoga posjedovanja određene kvalitete, studenti su se osvrnuli na svoju praksu, procijenili su same sebe pa su dobiveni neki slabiji rezultati. To pokazuje da studenti imaju dobru viziju o tome kakav treba biti dobar učitelj i da u isto vrijeme prepoznaju kako još imaju mjesta za osobni i profesionalni razvoj.

Kad se analiziraju navedene karakteristike (Tablica 2) koje su različite u dvije zemlje, čini se da hrvatski studenti, za razliku od turskih, smatraju da dobar učitelj treba biti kreativan, snalažljiv, susretljiv i pošten. Cubukcu (2006) je istražila kritičke mislilačke sklonosti turskih budućih učitelja te je utvrdila da su najvišom ocjenom ocijenili dimenziju otvorenosti. Taj rezultat autorica objašnjava time što se smatra da je poželjno da osoba bude tolerantna prema različitim stavovima te da pri donošenju odluka ne uvažava samo svoje mišljenje, već i mišljenje drugih. To što budući učitelji očekuju da dobar učitelj poštuje učenika te bude demokratičan i human je u skladu s njihovim kritičkim mislilačkim sposobnostima, kao što je utvrđeno u istraživanju autorice Cubucku (2006). Što se tiče profesionalnih kvaliteta učitelja, i hrvatski, i turski studenti slažu se u mišljenju da dobar učitelj treba biti pravedan i profesionalan. Što se tiče različitih kvaliteta, vidljivo je da su budući učitelji uglavnom usredotočeni na način poučavanja učitelja (otvorenost ka novim idejama, pouzdanost, objektivnost, marljivost itd.). No, budući učitelji iz Turske uglavnom naglašavaju kvalitete „utemeljene na znanju“ (dobar učitelj treba biti stručnjak u predmetnoj materiji, treba imati široko opće znanje itd.). Rezultati su također pokazali da hrvatski studenti više cijene važnost osobnih i profesionalnih kvaliteta učitelja kao i njihovo posjedovanje (Tablica 4). Rezultati su zanimljivi jer ih se djelomično može objasniti razlikom između sustava obrazovanja učitelja u Hrvatskoj i Turskoj.

Jedno od mogućih razloga zbog kojega su hrvatski studenti dali bolje rezultate može biti trajanje njihova studija. Neke beneficije koje pruža dugoročno brazovanje učitelja istaknute su u TELT istraživanju koje je pokazalo da sveučilišni programi obrazovanja učitelja više utječu na stjecanje znanja u studenata negoli školski programi (Kennedy, 1999). Možemo pretpostaviti da se hrvatski studenti vide u pozitivnijem svjetlu jer prolaze jednu godinu više svojega visokoškolskoga obrazovanja. Druga moguća 
razlika između Hrvatske i Turske koja je mogla utjecati na rezultate jest različit pristup sustavu odabira učitelja za državne škole u te dvije zemlje. Nakon diplome koju stječu na učiteljskim fakultetima, budući učitelji u Turskoj polažu ispit koji se zove selekcijski ispit za javno osoblje. Postoji sustav kvote za odabir učitelja koje se oslanjaju na njihovu uspješnost na tome ispitu. No, broj učitelja koji se mogu zaposliti ograničen je u usporedbi s brojem diplomiranih učitelja koji završavaju svoj studij svake godine. Stoga većina diplomiranih učitelja neće biti zaposlena jer im država ne osigurava dovoljno radnih mjesta. U istraživanju koje su proveli Kildan i dr. (2013), a kojemu je cilj bio ocijeniti stavove učitelja pripravnika na sustav obrazovanja učitelja u Turskoj, ispostavilo se da učitelji koji su u tijeku svoje prve godine rada smatraju da je spomenuti ispit najveći problem procesa obrazovanja učitelja u Turskoj. S obzirom na navedeno, problemi koji očekuju buduće učitelje nakon što diplomiraju možda djeluju na njihovu motivaciju za rad u struci kao i njihovo mišljenje o tome što je to dobar učitelj. Možda imaju manja očekivanja o tome što to znači biti učitelj u usporedbi s njihovim hrvatskim kolegama. Usprkos tome što u Hrvatskoj ima previše osnovnoškolskih učitelja, svi koji završe studij imaju jednaku priliku za zapošljavanjem.

Kad su istražene razlike u rezultatima prema godini studija na kojoj se pojedina skupina ispitanika nalazila u trenutku kad je istraživanje provedeno, pokazalo se da ne postoje razlike u ocjeni željenih profesionalnih kvaliteta u odnosu na razinu studija (Tablica 4). Ocjena željenih profesionalnih kvaliteta konstantno je prilično visoka tijekom cijelog razdoblja studija. Takvi rezultati pokazuju da budući učitelji na početku svojega studija imaju razvijeno razumijevanje o važnosti profesionalnih kvaliteta učitelja koje čini dio njihova identiteta učitelja (Korthagen, 2004), a koje često ostaje važan dio njihova razumijevanja učiteljske profesije.

Tablica 4.

S druge strane, u cijelom uzorku nisu vidljive razlike između mišljenja studenata prvih i završnih godina s obzirom na kategoriju profesionalne kvalitete koje ispitanik posjeduje. Studenti završnih godina ocijenili su posjedovanje profesionalnih kvaliteta učitelja višim ocjenama nego što su to učinili studenti početnih godina (Tablica 5). Goodson, \& Cole (1994) tvrde da je u budućih učitelja osjećaj za razvoj (novoga) profesionalnog identiteta ovisan o kontekstu u smislu njihova razvoja poimanja profesionalne zajednice. Prema tome, vrijeme koje su proveli u institucijama za obrazovanje učitelja utjecalo je na razvoj njihova osobnoga identiteta. Tijekom razdoblja obrazovanja budućih učitelja i hrvatski, i turski studenti pohađaju akademske kolegije koji im pomažu razviti se u području učiteljskoga zvanja i vještina podučavanja. Kombinacija znanja iz pedagogije i psihologije, kolegiji metodike podučavanja, poznavanje predmetnoga znanja te kolegiji posebno dizajnirani za razvoj svijesti o zanimanju učitelja (npr. kolegiji prakse) vode ka profesionalnom razvoju budućih učitelja. Ovakvi su rezultati očekivani te mogu potvrditi pozitivan učinak obrazovanja učitelja na njihov doživljaj svoje profesionalne spremnosti u 
smislu usvojenosti profesionalnih kvaliteta učitelja. Nisu pronađene razlike između kategorija poželjne osobne kvalitete i osobne kvalitete koje ispitanik posjeduje u odnosu na godinu studija ispitanika. To se može objasniti Ofmanovom (2001) teorijom prema kojoj se temeljne kvalitete (ili osobne kvalitete, kako su nazvane u ovome članku) ne stječu izvana te se stoga na njih ne može utjecati izvana tijekom obrazovanja budućih učitelja. To su kvalitete koje svaka osoba ima u sebi još prije nego upiše fakultet. Iako te kvalitete nije moguće namjerno usvojiti, na njih se može utjecati osvještavanjem i izgradnjom kapaciteta za njihovo korištenje u aktivnostima koje se obavljaju za vrijeme studija.

\section{Tablica 5.}

\section{Zaključak}

S obzirom na rezultate ovoga istraživanja zaključeno je da hrvatski budući učitelji, za razliku od njihovih turskih kolega, višim ocjenama ocjenjuju važnost i posjedovanje razina kvaliteta nastavnika. Pri usporedbi sustava tih dviju zemalja prva je razlika očita u trajanju njihova visokoškolskog obrazovanja. Ti rezultati pokazuju da trajanje početnog obrazovanja učitelj može imati pozitivan učinak na mišljenje studenata $o$ razvoju njihovih profesionalnih kvaliteta učitelja. Alsup (2005) smatra da, usprkos tome što je oblikovanje učiteljeva profesionalna identiteta prilično osobna stvar, programi obrazovanja učitelja mogu imati velik utjecaj i u tom smislu.

Razlike među ocjenama osobnih kvaliteta s obzirom na godinu studija nisu značajne na razini ukupnoga uzorka. Rezultati istraživanja potvrđuju Ofmanove (2001) tvrdnje o tome da se osobne kvalitete ne stječu izvana. S obzirom na to da se ne stječu izvana, na njih se izvana ne može niti utjecati stupnjem obrazovanja te se one značajno ne mijenjaju s godinama studija. Dall Alba (2009) navodi da budući učitelji tijekom svojega studija ostaju iste osobe kakve su bili pri upisu studija, ali da $\mathrm{u}$ isto vrijeme prolaze i svojevrsne promjene u smislu razvoja svojih kapaciteta za izvođenje nastave i razumijevanje toga što uključuje podučavanje.

Glavna je razlika pronađena u ocjenjivanju profesionalnih kvaliteta na razini ukupnoga uzorka. Budući učitelji na svojoj završnoj godini studija ocjenjuju posjedovanje svojih profesionalnih kvaliteta znatno pozitivnije od studenata na prvoj godini studija. Profesionalnost učitelja je kompleksna, usađena je u kontekst podijeljenih normi, vrijednosti i pogleda u profesionalnoj skupini, ali je također osobna i individualna. Rezultati ovoga istraživanja pokazali su da usredotočenje na „individualni profesionalizam“ $\mathrm{i}$ individualne vrijednosti tijekom studija može potaknuti znatne promjene u profesionalnim identitetima budućih učitelja. Pelton (2013) se usredotočuje na polje djelovanja programa obrazovanja učitelja te kaže da, uz to što su učinkoviti, programi obrazovanja učitelja čak mogu umanjiti strah od podučavanja. Chong i dr. (2011) tvrde da je većina razmatranja identiteta učitelja bila usredotočena na njegovu izgradnju tijekom početnih godina podučavanja, kao i cijele karijere. Manje se proučavao identitet učitelja koji se izgrađuje tijekom ranih 
godina njihova obrazovanja, a još manje razlike do kojih dolazi između trenutka upisa u programe obrazovanja učitelja i njihova završetka. Čini se da budući učitelji imaju jasnu ideju o tome koji elementi čine dobrog i kvalitetnog učitelja te ih mogu identificirati. Razlika je u tome što se studenti posljednje godine studija doživljavaju profesionalnijima.

No, trebamo biti pažljivi pri interpretaciji ovih rezultata. S obzirom na to da ne postoji dodatan način ocjenjivanja kvaliteta učitelja (skale osobnosti ili ocjenjivanje kolega), ovi rezultati prikazuju samo mišljenje budućih učitelja.

Alsup (2005) smatra da je osjećaj uspješnosti u učitelja povezan s poimanjem profesionalnoga identiteta koji u sebi sadrži intelektualne, emocionalna i tjelesne vidove života učitelja kao i subjektivnost „,učitelja“. To znači da bi učitelji trebali biti u stanju povezati „temeljni“ identitet ili osobna uvjerenja i svijest o sebi sa svojim profesionalnim identitetom.

Važnost dobrog/učinkovitog/uspješnog učitelja globalno je prepoznata, no ipak još uvijek većina ljudi misli da učitelji završavaju svoje obrazovne programe bez da stječu potrebna znanja i vještine za učinkovit rad u praksi (Hodgman, 2012, 223). Maandag i dr. (2007) također naglašavaju ovo gledište te kažu da se programi obrazovanja učitelja kritiziraju zbog toga što ne pružaju profesionalni trening koji današnja društva zahtijevaju. Stoga je iznimno važno da budući učitelji tijekom svojega studentskoga života istraže i identificiraju svoje temeljne i profesionalne kvalitete kako bi mogli razviti svoj profesionalni identitet, osobne pedagogije i jasnu misiju. Zaključujemo slažući se s Korthagenovim (2004) prijedlogom implementacije holističkoga pristupa obrazovanju učitelja u kojemu kompetencija nije izjednačena s kompetencijama. 